\title{
Screening the antifungal activity of essential oils against decay fungi from palmyrah leaf handicrafts
}

\author{
Subajini Mahilrajan ${ }^{1}$, Jeyarani Nandakumar ${ }^{2 *}$, Robika Kailayalingam', Nilushiny Aloysius Manoharan ${ }^{1}$ \\ and SriThayalan SriVijeindran ${ }^{1}$
}

\begin{abstract}
Background: The whitish tender leaves of Palmyrah are used for making handicrafts. The problem with these articles is discolouration with time and become more brittle due to fungal attack. This could be prevented by some protective coating. Instead of expensive and harmful chemicals we decided to test natural plant essential oils to control fungal attack. Palmyrah leaf article decay fungi were isolated from two different sites of Jaffna peninsula. In this investigation Antifungal Activity of different plant essential oils from neem (Azadirachta indica), castor (Ricinus communis), citronella (Cymbopogon sp) and camphor (Cinnamomum camphora) obtained from local market have been evaluated against isolated fungi. For screening of Antifungal activity, tests and controls were set to determine minimum inhibitory concentration (MIC) and Percentage of Growth Inhibition.

Results: Morphologically three different types of Palmyrah leaf decay fungi were isolated and characterized as Aspergillus niger, Aspergillus flavus and Penicillium sp. Neem and castor oils have recorded no significant $(0.05>P)$ antifungal activity while citronella and camphor oils showed significantly different antifungal activity compared with control. Camphor oil and Citronella oil showed 100, 58.13\% of average growth inhibition for A. niger. 96.38, 51.32\% for A.flavus and $84.99,72.76 \%$ for Penicillium sp respectively. Camphor oil showed highest percentage of growth inhibition at lowest minimum inhibitory concentration compared with citronella oil. Camphor oil was found to be highly antifungal and most effective against A niger, and A. flavus, compared with Penicillium sp and gave 100 percentage of growth inhibitions at 5,1 and $15 \mathrm{ml} / \mathrm{dl}$ minimum inhibitory concentration respectively.

Conclusion: Significantly higher broad-spectrum of antifungal activity was observed in camphor oil than other tested oils because it showed highest percentage of growth inhibition at lowest inhibitory concentration. Therefore it could be used for the development of new environmental friendly antifungal agent for the preservation of leafy handicrafts. Further formulation, field experiments are necessary to achieve this target.
\end{abstract}

Keywords: Essential oil, Growth inhibition, Minimal inhibitory concentration and Palmyrah leaf

\section{Background}

Borassus flabellifer Linn (Palmyrah palm) these palm trees grow in a dry climate. The leaves of the palmyrah palm are thick, fibrous, initially strong and flexible, over time its flexibility decreases which is used to make handicrafts. They are also susceptible to insect attacks [1] and the lignified cells are particularly susceptible to degradation and discoloration. If not preserved properly they

\footnotetext{
* Correspondence: jeyaraninandakumar@yahoo.com

${ }^{2}$ Department of Botany, University of Jaffna, Jaffna, Sri Lanka

Full list of author information is available at the end of the article
}

are subject to physical and fungal damage. Some of the most common deteriorating agents are climatic factors (e.g. variations in relative humidity and temperature) [1]. Agrawal [2] reported that conservation of palm leaf manuscripts using of citronella oil, camphor oil, or lemon grass oil on the surface of the leaf to keep it flexible. This prevents physical damage due to brittleness.

Essential oils are complex mixers comprising many single compounds. Chemically they are derived from terpenes and their oxygenated compounds. Each of these constituents has been shown to possess antibacterial, 
antifungal, antiviral insecticidal and antioxidant properties $[3,4])$. The antimicrobial activity of different essential oils is known for many centuries. Large number of essential oils and their constituents were investigated for their antimicrobial properties against different bacteria and fungi strains $[5,6]$.Among the essential oils citronella oil has shown inhibitory effect on biodegrading and storage of contaminating fungi [7].

Fungi are significant destroyers not only of foodstuffs, grains but also in leaves during storage, unfit for human consumption by retarding their nutritive value and often by producing mycotoxins $[8,9]$. A sizeable portion of the world population living below poverty line in the developing and underdeveloped countries of Asia and Africa are suffering from health problems associated with consuming mycotoxin contaminated grains and cereals [10]. Even though effective and efficient control of air borne fungi can be achieved by the use of synthetic chemical fungicides; the same cannot be applied to leaf for reasons of pesticide toxicity [11-13] and durability of the leaf. Thus, there is a need to search for alternative approaches to store palmyrah leaf handicrafts without toxicity problems that are ecofriendly and cost effective.

\section{Results and discussion}

\section{Isolation of palmyrah leaf article decay fungi}

The palmyrah leaf is used for roofing, handicrafts and feed for livestock. The first two tender unexpanded whitish leaves and the next 12 young green leaves are used for making various handicrafts. The whitish tender leaves are used for making soft fine handicrafts while the young green leaves are used for making stronger, but coarse textured utility items like mats, baskets, packaging material, inner lining of heavy duty fibre baskets etc. The fungi affected palmyrah tender leaf articles were selected and using inoculation needle different colour colonies were inoculated into the PDA plate then incubated at room temperature for 4 days. After incubation black (B), green (G) and bluish green (A) colour of the colonies were observed. These three different colour colonies were selected for further study. Selected colonies were purified by repeated streaking. The purified fungi were maintained in agar slants at $4^{\circ} \mathrm{C}$ throughout the study and used as stock cultures.

\section{Characterization of isolated fungal strains}

Selected fungi B, G \& A were identified as Aspergillus niger, Aspergillus flavus andPenicillium sp respectively at species level in based on macroscopic and microscopic features (Table 1).

\section{Antifungal activity assay}

All species of fungi, using of any concentrations caused significant differences $(p<0.05)$ on inhibitory effect of
Table 1 Macroscopic and microscopic features of isolated fungus

\begin{tabular}{|c|c|c|c|}
\hline Characteristics & B & G & A \\
\hline Colony colour & $\begin{array}{l}\text { Black with } \\
\text { white reverse }\end{array}$ & $\begin{array}{l}\text { Green with } \\
\text { cream reverse }\end{array}$ & $\begin{array}{l}\text { Bluish green with } \\
\text { white revers }\end{array}$ \\
\hline Hyphae & Septate hyaline & Septate hyaline & Septate hyaline \\
\hline Conidial head & Radiate & Radiate & Radiate \\
\hline Conidiophore & Smooth hyaline & Smooth hyaline & Simple \\
\hline Vesicle & Globose & Subglobose & - \\
\hline Conidia & Black globose & Globose & $\begin{array}{l}\text { Round, Unicellular } \\
\text { Unbranch }\end{array}$ \\
\hline Phialide & Unisereate & Bisereate & \\
\hline
\end{tabular}

essential oils. It could be seen that as essential oils concentrations increases the inhibitory effect increases (Figures 1, 2 and 3). In other words, the inhibitory effect of the essential oils was proportional to its concentration. This is in accordance with $[14,15]$. Whereas increase in concentrations the susceptibility of fungi increases as well (Figure 4).

Until now, there were no reports on the effects of essential oils on Palmyrah leaf decay fungi. Based on our findings, camphor oil affected the growth inhibition of the studied fungi. In all studied fungi, the essential oils caused significant differences $(\mathrm{p}<0.05)$ on growth inhibition rates. In other words, the effects of growth inhibitory of plant essential oils depend on species of fungi [15].

The results showed that two plant essential oil such as citronella and camphor oil caused $100 \%$ of growth inhibition on all species of fungi at $25 \mathrm{ml} / \mathrm{dl}$ concentration while neem and castor oil not caused $100 \%$ of GI at same concentration. Therefore lower concentrations (10, 15 and $20 \mathrm{ml} / \mathrm{dl})$ of each essential oils were used to determine the MIC on these fungi (Table 2). Camphor oil was the most effective essential oil on the $A$. niger, $A$. flavus and Peniillium with growth inhibition average of $100,96.38$ and $84.99 \%$ respectively. Whereas the citronella oil showed minor effect on A. niger, A. flavus and Peniillium with growth inhibition average of 58.13, 51.32 and $72.76 \%$ respectively.

GI of $A$. niger was showed higher significant difference $(\mathrm{p}<0.05)$ for citronella oil at $25 \mathrm{ml} / \mathrm{dl}$ and all the concentrations of camphor oil when compared with other oils similarly A. flavus showed higher significant difference $(\mathrm{p}<0.05)$ for citronella oil at $25 \mathrm{ml} / \mathrm{dl}$ and camphor oil at 5,10 and $15 \mathrm{ml} / \mathrm{dl}$ when compared with other oils while Penicillium showed higher significant difference ( $\mathrm{p}<0.05$ ) only for $25 \mathrm{ml} / \mathrm{dl}$ of citronella and $15 \mathrm{ml} / \mathrm{dl}$ of camphor oil. Penicilliumsp that isolated from palmyrah leaf was the most sensitive and most resistant to the studied essential oils.

Essential oils have two prominent features; low toxicity for people and environment due to their natural properties 


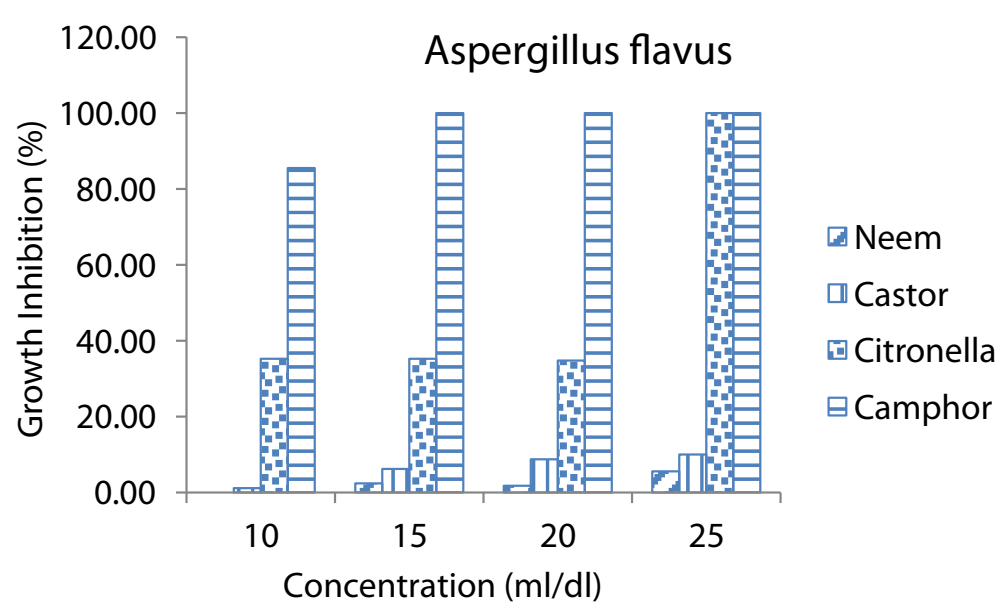

Figure 1 Average growth inhibition of essential oils at different concentrations on Aspergillus flavus.

and low risk for resistance development by pathogenic microorganisms [16]. For these reasons and considering the results, we recommend the use of camphor oils for development of new and safe antifungal agent for the preservation of leafy handicrafts.

\section{Conclusion}

The results showed that citronella and camphor oils were very effective on Aspergillus niger,Aspergillus flavus and Penicillium sp. (palmyrah leaf article decay fungi)with growth inhibition average of $100 \%$ at $25 \mathrm{ml} / \mathrm{dl}$ concentration. Nevertheless, MIC of the essential oils was variable depending to species of fungi. Penicillium $s p$. was the most sensitive and most resistant to the camphor oil with $100 \%$ growth inhibition at $15 \mathrm{ml} / \mathrm{dl}$ concentration. Since growth inhibition of studied essential oils were evident in this study, they have potential to control of these palmyrah leaf article decay fungi and could be considered for developing new antifungal agent. Further field study need to be done to find out whether the use of this essential oil will prevent these fungal growth on leaf handicrafts after using this essential oil at cottage level handicraft industries in Sri Lanka.

\section{Methods}

Essential oils

The essential oils such as neem oil, castor oil, citronella oil and camphor oil, obtained from local market and exposed to UV radiation for $10 \mathrm{~min}$ then these oils were used for this study. These oils were selected based on literature survey and their use in preservation of leaf articles.

\section{Isolation of palmyrah leaf decay fungi collection of sample}

Palmyrah handicrafts are usually affected by fungus during rainy season. Affected tender leaf articles of Palmyrah were collected from two design centers of Palmyrah Development Board during rainy season and used for the isolation of Palmyrah leaf article decay fungus.

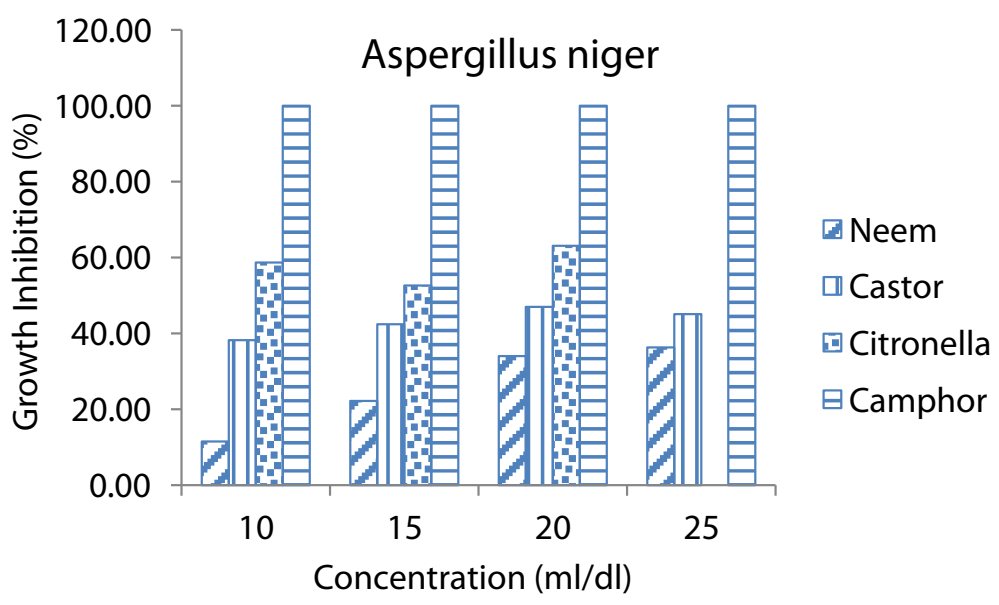

Figure 2 Average growth inhibition of essential oils at different concentrations on Aspergillus niger. 


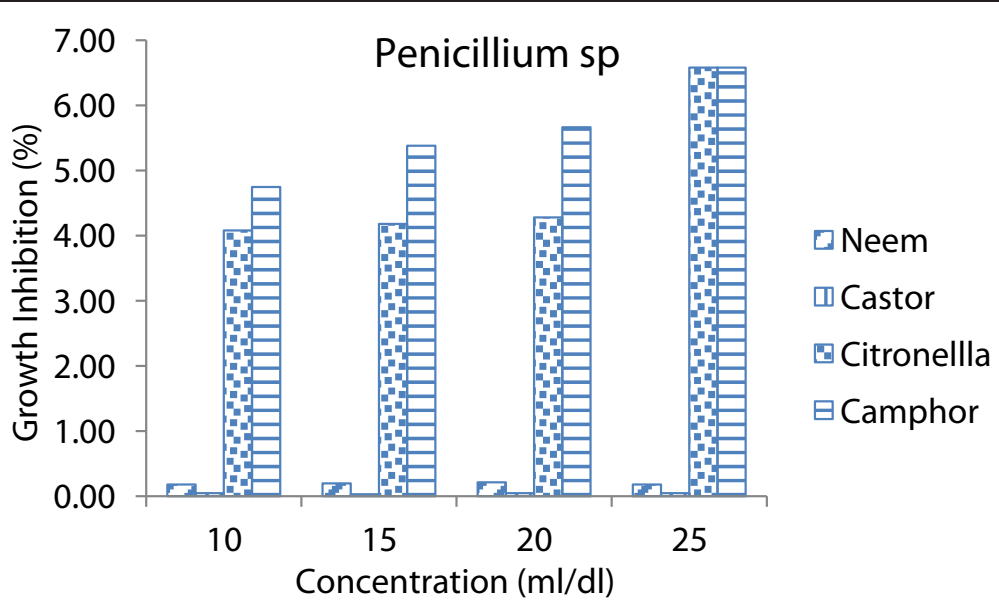

Figure 3 Average growth inhibition of essential oils at different concentrations on Penicilliumsp.

\section{Preparation of potato dextrose agar media PDA plates}

Potato Dextrose Agar medium was prepared according to the manufacturer's direction. After sterilization, the medium was allowed to cool to $50^{\circ} \mathrm{C}$ and poured in to sterile petridishes $(20 \mathrm{~mL} /$ Petridish) under aseptic condition.

\section{PDA slants}

The PDA was prepared according to the manufacturer's direction and $7 \mathrm{~mL}$ of the medium was poured into boiling tubes. The tubes were plugged with cotton wool and sterilized at $121^{\circ} \mathrm{C}$ and $15 \mathrm{lb} / \mathrm{in}^{2}$ for $15 \mathrm{~min}$. The tubes were then cooled in an inclined position and used for storage of the fungus.

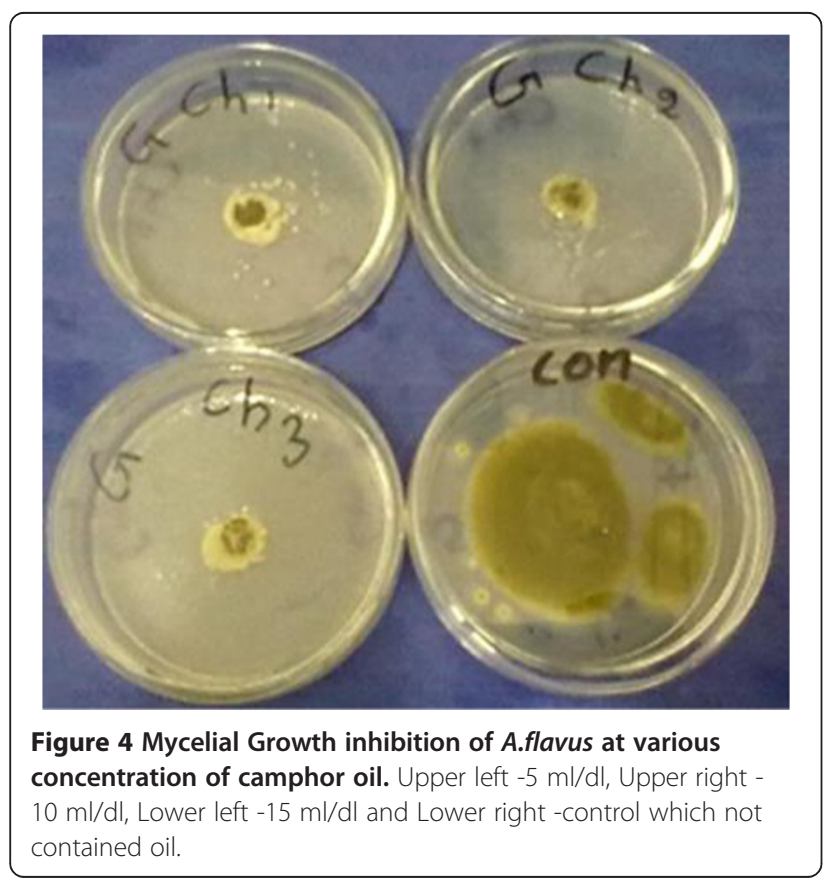

\section{Isolation of fungal strains}

Fungus affected leaf handicrafts were brought to laboratory and using inoculation needle different colour colonies were streaked on sterile PDA plates in Zig-Zag manner and incubated at room temperature for 3- 4 days. Selected colonies were purified by repeated streaking and transferred to PDA slants and kept at $4{ }^{\circ} \mathrm{C}$.

Table 2 Growth inhibition (\%) and MIC of essential oils

\begin{tabular}{|c|c|c|c|c|c|c|}
\hline \multirow{3}{*}{$\begin{array}{c}\text { Essential } \\
\text { oils (v/v) (ml/dl) }\end{array}$} & \multicolumn{6}{|c|}{ Fungus } \\
\hline & \multicolumn{2}{|c|}{ Aspergillusniger } & \multicolumn{2}{|c|}{ Aspergillusflavus } & \multicolumn{2}{|c|}{ Penicilliumsp } \\
\hline & GI (\%) & MIC & GI (\%) & MIC & GI (\%) & MIC \\
\hline \multicolumn{7}{|l|}{ Neem } \\
\hline 10 & 0.00 & & 11.52 & & 2.74 & \\
\hline 15 & 2.41 & & 22.00 & & 2.99 & \\
\hline 20 & 1.77 & & 34.02 & & 3.24 & \\
\hline 25 & 5.58 & & 36.31 & & 2.74 & \\
\hline \multicolumn{7}{|l|}{ Castor } \\
\hline 10 & 1.14 & & 38.22 & & 0.71 & \\
\hline 15 & 6.21 & & 42.41 & & 0.46 & \\
\hline 20 & 8.75 & & 46.99 & & 0.71 & \\
\hline 25 & 10.01 & & 45.08 & & 0.71 & \\
\hline \multicolumn{7}{|l|}{ Citronella } \\
\hline 10 & 35.24 & & 58.68 & & 62.01 & \\
\hline 15 & 35.24 & & 52.62 & & 63.53 & \\
\hline 20 & 34.78 & & 63.09 & & 65.05 & \\
\hline 25 & 100.00 & * & NA & & 100.00 & * \\
\hline \multicolumn{7}{|l|}{ Camphor } \\
\hline 1 & 85.51 & & 100.00 & * & 72.14 & \\
\hline 05 & 100.00 & * & 100.00 & & 81.76 & \\
\hline 10 & 100.00 & & & & 07 & \\
\hline 15 & 100.00 & & 100.00 & & 100.00 & * \\
\hline
\end{tabular}

Gl: Growth inhibition (\%), MIC: Minimum Inhibitory Concentra. 


\section{Characterization of isolated fungal strains}

Selected fungal colonies were identified to species level based on macroscopic morphology and microscopic features.

\section{Antifungal activity assay}

PDA medium with $1,15,20$ and $25(\mathrm{ml} / \mathrm{dl})$ concentrations of the essential oils such as neem, castor \& citronella and $1,5,10 \& 15(\mathrm{ml} / \mathrm{dl})$ of concentrations camphor oil were prepared. About $15 \mathrm{~mL}$ of the medium was poured into each petridish, Tween-20 (Sigma) was incorporated into the agar medium to enhance oil solubility and allowed to solidify. Nine mm disc of 5 days old culture of the test fungi from the margin of the plates were placed at the center of the petridishes and incubated at room temperature for 4 days. After incubation the colony diameter was measured in millimeter. For each treatment three replicates were maintained. PDA medium without the essential oil served as control. Growth zones were measured at $4^{\text {th }}$ and $6^{\text {th }}$ days of incubation. The fungi toxicity of the oils in terms of percentage of growth inhibition of mycelia was calculated by using the formula:

$$
\text { Growth inhibition }(\%)=\mathrm{dc}-\mathrm{dt} / \mathrm{dc} \times 100
$$

Where $\mathrm{dc}=$ Average increase in mycelial growth in control,

$\mathrm{dt}=$ Average increase in mycelial growth in treatment [17].

The antifungal agent nystatin added to the agar plates (final concentration of $1.0 \mathrm{mg} / \mathrm{l}$ ) served as a positive control for Aspergillus niger, A. flavus and penicillium $\mathrm{sp}$.

\section{Statistical analysis}

MIC and percentage of inhibition were analysed by SAS package and the mean separation was done by LSD at $\mathrm{p}=0.05$.

\section{Competing interests}

The authors declare that they have no competing interests.

\section{Authors' contribution}

JN- supervised the research project SM, JN\&RK carriedout the antimicrobial activity study; participated in isolation of fungus from Palmyrah handicrafts. JN\&SM- Drafted the manuscript. NAM- carriedout statistical analysis. SSV- coordinated \& management of research activities. All authors read and approved the final manuscript.

\section{Acknowledgements}

The authors thank Ministry of traditional industries and small enterprise development, Sri Lanka for financial support.

\footnotetext{
Author details

${ }^{1}$ Palmyrah Research Institute, Kaithady, Jaffna, Sri Lanka. ${ }^{2}$ Department of Botany, University of Jaffna, Jaffna, Sri Lanka.
}

Received: 18 March 2014 Accepted: 16 July 2014

Published: 15 August 2014

\section{References}

1. Udaya D, Kumar GV, Sreekumar U, Athvankar A: Traditional Writing System in Southern India - Palm Leaf Manuscripts. Southern India: Palm leaf manuscripts; 2009

2. Agrawal and Om Prakesh: Conservation of Manuscripts and Paintings of South-east Asia. London: Butterworths\& Co Ltd; 1984:43-48.

3. Burt SA: Essential oils: their antibacterial properties and potential applications in foods: a review. Inter J Food Microbiol 2004, 94:223-253.

4. Kordali S, Kotan R, Mavi A, Cakir A, Ala A, Yildirim A: Determination of the chemical composition and antioxidant activity of the essential oil of artemisia dracunculus and of the antifungal and antibacterial activities of Turkish artemisia absinthium, a. Dracunculus, artemisia santonicum, and artemisia spicigera essential oils. J Agric Food Chem 2005, 53:9452-9458.

5. Bakkali F, Averbeck S, Averbeck D, Idaomar M: Biological effects of essential oils. A review. Food ChemToxicol 2008, 46:446-475.

6. Kalemba D, Kunicka A: Antibacterial and antifungal properties of essential oils. Curr Med Chem 2003, 10(10)

7. De Billerbeck VG, Roques CG, Bessiere JM, Fonvieille $J$, Dargent R: Effects of cymbopogonnardus(L.) W. Watson essential oil on the growth and orphogenesis of aspergillusniger. Can J Microbiol 2001, 47:9-17.

8. Marin S, Homedes V, Sanchis V, Ramos AJ, Magan N: Impact of Fusariummoniliforme and F. proliferatumcolonisation of maize on calorific losses and fumonisin production under different environmental conditions. J Stored Prod Res 1999, 35:15-26.

9. Janardhana GR, Raveesha KA, Shetty HS: Modified atmosphere storage to prevent mould-induced nutritional loss in maize. J Sci Food Agri 1998, 76:573-578

10. Majumder UK, Gupta M, Mukhopadhyay DK: Effect of mycotoxins isolated from Penicilliumnigricans on glucose-6-phosphate dehydrogenase. Indian J Exp Biol 1997, 35:1233-1236.

11. Ferrer A, Cabral R: Toxic epidemics caused by alimentary exposure to pesticides: a review. Food Additives Contamin 1991, 8:755-776.

12. Harris CA, Renfrew MJ, Woolridge MW: Assessing the risk of pesticide residues to consumers: recent and future developments. Food additives Contaminat 2001, 18:1124-1129.

13. Dukic NM, Bozin B, Sokovic M, Simin N: Antimicrobial and antioxidant activity of melissa officinalisL. (lamiaceae) essential oil. J Agri Food Chem 2004, 52:2485-2489.

14. Rasooli I, Rezaei MB, Allameh A: A. Growth inhibition and morphological alterations of aspergillusnigerby essential oils from thymus eriocalyxand thymus xporlock. Food Control 2006, 17:359-364.

15. Amini M, Safaie N, Salmani MJ, And Shams-Bakhsh M: Antifungal activity of three medicinal plant essential oils against some phytopathogenic fungi. Trakia J Sci 2012, 10:1-8.

16. Daferera DJ, Ziogas BN, Polissiou MG: GC-MS analysis of essential oils from some greek aromatic plants and their fungitoxicity on Penicilliumdigitatum. J Agric Food Chem 2000, 48:2576-2581.

17. Singh J, Tripathi NN: Inhibition of storage fungi of blackgram (Vignamungo) by some essential oils. Flavour Fragr J 1999, 14:1-4.

doi:10.1186/0717-6287-47-35

Cite this article as: Mahilrajan et al:: Screening the antifungal activity of essential oils against decay fungi from palmyrah leaf handicrafts. Biological Research 2014 47:35.

\section{Submit your next manuscript to BioMed Central and take full advantage of:}

- Convenient online submission

- Thorough peer review

- No space constraints or color figure charges

- Immediate publication on acceptance

- Inclusion in PubMed, CAS, Scopus and Google Scholar

- Research which is freely available for redistribution 